\title{
GMR
}

\section{Increased relatedness among the neighboring plants from seedling to adult stages in carnaúba wax palm}

\author{
F.A. Vieira ${ }^{1}$, R.F. Sousa ${ }^{1}$, C.G. Fajardo ${ }^{1}$ and M.M. Brandão ${ }^{2}$ \\ ${ }^{1}$ Universidade Federal do Rio Grande do Norte, Macaíba, RN, Brasil \\ ${ }^{2}$ Universidade Estadual de Montes Claros, Montes Claros, MG, Brasil \\ Corresponding author: F.A. Vieira \\ E-mail: vieirafa@gmail.com
}

Genet. Mol. Res. 15 (4): gmr15049100

Received August 29, 2016

Accepted November 9, 2016

Published December 19, 2016

DOI http://dx.doi.org/10.4238/gmr15049100

Copyright $(2016$ The Authors. This is an open-access article distributed under the terms of the Creative Commons Attribution ShareAlike (CC BY-SA) 4.0 License.

\begin{abstract}
The objective of this study was to assess the spatial genetic structure (SGS) at different life stages (cohorts) in a remnant population $(\mathrm{N}=101)$ of Copernicia prunifera in the semiarid region of northeastern Brazil. Using seven inter-simple sequence repeat molecular markers, we were able to analyze 93 loci with $100 \%$ polymorphism. Seedlings had the highest level of genetic diversity $\left(H_{\mathrm{E}}=0.411, H_{\mathrm{O}}\right.$ $=0.599)$, followed by juveniles $\left(H_{\mathrm{E}}=0.394, H_{\mathrm{O}}=0.579\right)$ and adults $\left(H_{\mathrm{E}}=0.267, H_{\mathrm{O}}=0.427\right)$. Based on analysis of molecular variance, the majority of genetic variations were observed to occur within the life stages $(93.42 \%)$ rather than between the life stages (6.58\%). We found a recent reduction in the population size (bottleneck) based on the number of loci with heterozygosity excess for the two models used (infinite allele $=92$ and stepwise $=91$ ). All the life stages showed significant SGS, with positive and significant kinship values. $S p$ values were 0.040 for seedlings, 0.093 for juveniles, 0.156 for adults, and
\end{abstract}


0.053 for the total population. We found an increase in SGS from the seedling to adult stages, indicating that the plants were from related adult progenitors. Data from this study can be used in designing effective management and conservation strategies for the species.

Key words: Northeastern Brazil; ISSR; Molecular markers; Copernicia prunifera; Spatial genetic structure

\section{INTRODUCTION}

Populations of species exist in various environments that are different in time and space and are affected by many factors, such as weather, natural disasters, pathogens, and herbivore attacks (Condit et al., 2000; Ng et al., 2004), which directly impact the geographical distribution, structure, and genetic diversity of the species (White and Walker, 1997). The distribution patterns of genetic variability in species can reveal ecological and biological aspects, including pollination and seed dispersal mechanisms of the species (Gonçalves et al., 2010; Silva et al., 2011; Brandão et al., 2015). In addition, genetically less diverse populations are particularly vulnerable to extinction, whereas populations with large numbers of genotypes are more likely to be resistant to deleterious influences (Van Treuren et al., 1991). Therefore, genetic diversity is a key factor for development of species over time; it enables the species to adapt to the environmental changes. The genetic composition of a population influences the way its members will adapt to future environmental changes (Hoffmann and Willi, 2008).

The diversity and genetic structure of a species is fundamental for management, conservation, or domestication of the species (Cota et al., 2011). The population genetic structure can be analyzed using molecular markers, such as inter-simple sequence repeat (ISSR; Zietkiewicz et al., 1994). The polymorphism detected by this technique is binary; the technique normally detects only one allele per locus (Reddy et al., 2002). It is possible to assess the diversity of a population, as well as its spatial genetic structure using the ISSR markers. From a conservationist point of view, these observations in the study may contribute directly to strategies aimed at maintaining genetic diversity in reforestation, management, and regeneration programs in degraded areas (Gonçalves et al., 2010; Souza and Lovato, 2010).

To develop an in situ conservation plan, it is essential to understand the levels of genetic variability and the spatial distribution of genotypes within the populations. Previous studies on the genetic structure show that the individuals located close to each other tend to be related and usually there is greater genetic diversity within than there is among the life stages (Lacerda and Kageyama, 2003; Rossato et al., 2007). This variation might be the result of different ecological and genetic factors operating in the natural populations, as well as the varying spatial-temporal sampling and statistical methods used in the study (Vekemans and Hardy, 2004). In addition, the scale and magnitude of genetic structure may also differ significantly among the life stages, with seedlings often exhibiting greater structure within populations compared with the adults ( $\mathrm{Ng}$ et al., 2004).

Copernicia prunifera (Arecaceae), commonly known as carnaúba, naturally occurs in northeastern Brazil. The species has an erect trunk with unique sheaths or residual leaf bases that remain on the trunk (Rodrigues et al., 2013). In rural areas, the trunk is used in construction of houses and animal corrals. The perennial leaves are numerous (from 45 to 60 leaves per individual) and the canopy is round. The species produces a branched inflorescence

Genetics and Molecular Research 15 (4): gmr15049100 
that is longer than the leaves; the flowers are pollinated by bees and the flowering is subannual (Rocha et al., 2015). C. prunifera has diploid number of chromosome $(2 \mathrm{n}=36)$ (Môro et al., 1999). The fruits are spherical with a smooth, dark epicarp when mature and are dispersed by bats (Sousa et al., 2015). The fasciculate roots have medicinal properties (Rodrigues et al., 2013). The present study aimed to determine the variability of spatial genetic structure (SGS) among the different life stages (seedlings, juveniles, and adults) in a carnaúba population using ISSR molecular markers.

\section{MATERIAL AND METHODS}

\section{Study site and sampling}

The study population is a natural C. prunifera stand located in Macaíba ( $5^{\circ} 53^{\prime} 57^{\prime \prime} \mathrm{S}$, $\left.35^{\circ} 22^{\prime} 59^{\prime \prime} \mathrm{W}\right)$, Rio Grande do Norte State, Brazil. The region has an average annual precipitation of $1243.5 \mathrm{~mm} /$ year. According to the Köppen classification, the climate is a transition between As (tropical) and BSh (dry) climates, with dry summers and rainy winters. The local vegetation is predominantly Caatinga (arboreal and shrubby), with transitional vegetation of the Atlantic Forest (Cestaro and Soares, 2004); it has suffered a high degree of human interference, such as deforestation and road construction. This remnant C. prunifera population was chosen because it clearly presents the three main stages of ecological succession: seedlings (height ranging between 0.20 to 1.00 meters), juveniles (greater than 1.00 meters tall, non-reproductive), and adults (reproductive). The study area is also being subjected to desertification, and is, thus, a priority for conservation.

Within the population, all the 101 individuals were sampled and $\mathrm{X}$ and $\mathrm{Y}$ coordinates were recorded (Figure 1). Plant height was estimated using a steel measuring tape. We assessed the presence or absence of reproductive structures, such as flower buds, flowers, and fruit of all the individuals present in the area, to identify adult individuals. The leaf samples were collected and stored in a freezer at $-20^{\circ} \mathrm{C}$ until DNA extraction.

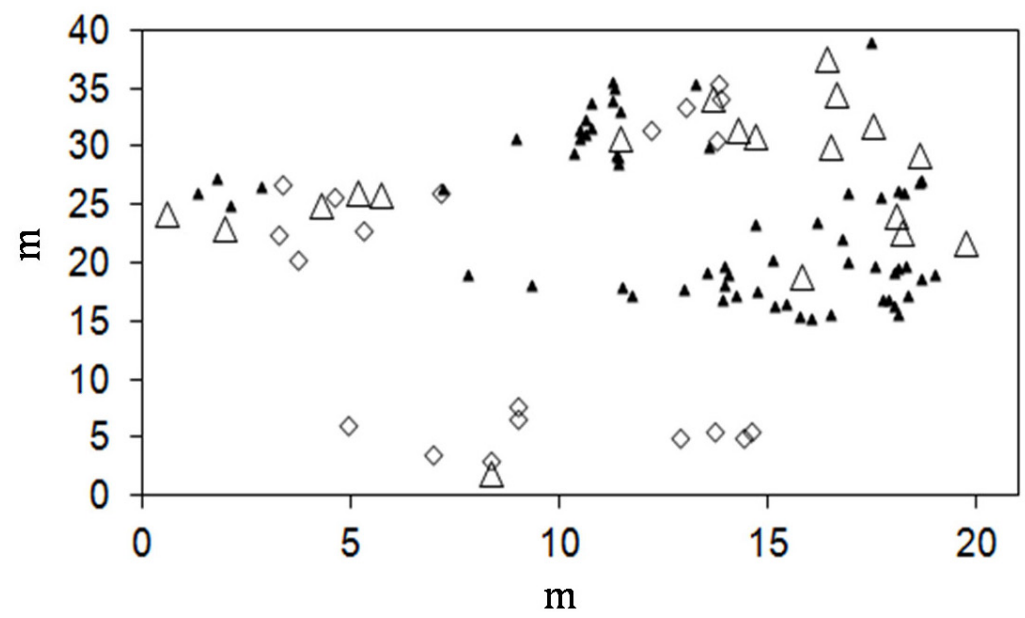

Figure 1. Position and spatial distribution of Copernicia prunifera individuals. Large triangles indicate adults; diamonds indicate juveniles; filled triangles indicate seedlings.

Genetics and Molecular Research 15 (4): gmr15049100 


\section{DNA extraction, amplification of ISSR, and electrophoresis}

DNA was extracted using the CTAB (cetyltrimethylammonium bromide) method, proposed by Doyle and Doyle (1990). Polymerase chain reaction (PCR) was subsequently carried out using 17 ISSR universal primers designed at the University of British Columbia (UBC). The PCR mix consisted of 10X buffer, $1.0 \mathrm{mg} / \mathrm{mL} \mathrm{BSA}, 50 \mathrm{mM} \mathrm{MgCl}, 2.5 \mathrm{mM}$ dNTPs, $2 \mu \mathrm{M}$ primer, $0.5 \mathrm{U}$ Taq polymerase, a 1:50 dilution of DNA, and ultrapure water. The PCRs were conducted using a Veriti automatic thermocycler in which the samples were initially denatured at $94^{\circ} \mathrm{C}$ for $5 \mathrm{~min}$, followed by 37 amplification cycles of $94^{\circ} \mathrm{C}$ for $15 \mathrm{~s}$, $47^{\circ} \mathrm{C}$ for $30 \mathrm{~s}$, and $72^{\circ} \mathrm{C}$ for $1 \mathrm{~min}$. The reaction was concluded with a final extension step of $72^{\circ} \mathrm{C}$ for $7 \mathrm{~min}$, followed by cooling at $4^{\circ} \mathrm{C}$. The PCR products were analyzed by horizontal electrophoresis on $1.5 \%$ agarose gel, in $0.5 \mathrm{X}$ Tris-Borate EDTA buffer, at $120 \mathrm{~V}$. The gels were stained with GelRed ${ }^{\mathrm{TM}}$ and photographed under ultraviolet light using E-Box VX2 equipment to observe the DNA fragments.

\section{Data analysis}

\section{Diversity and genetic structure}

We used the POPGENE program version 1.3 to analyze the genetic diversity within the studied population (Yeh et al., 1997), including the number of observed alleles $\left(N_{\mathrm{A}}\right)$, effective number of alleles $\left(N_{\mathrm{E}}\right)$, Nei's genetic diversity $\left(H_{\mathrm{E}}\right)$, and Shannon Index $\left(H_{\mathrm{O}}\right)$ for each life stage. The ALERQUIM 3.0 program (Excoffier et al., 2007) was used for analysis of molecular variance (AMOVA) among the different life stages. This analysis uses molecular data to estimate the population differentiation and allows for hypothesis testing related to such differentiation.

\section{$S G S$}

For analyzing the SGS, we estimated the kinship coefficient between pairs of individuals (Hardy, 2003) in the total sample and for each of the three life stages using the SPAGeDi program, v.1.2g (Hardy and Vekemans, 2002). To analyze the intensity of SGS in each cohort, the $S p$ was calculated using the formula $S p=-b_{\log } /\left(1-F_{\mathrm{IJ}(1)}\right)$, where $-b_{\log }$ is the regression slope of the kinship coefficient curve and $F_{\mathrm{IJ}(1)}$ is the kinship coefficient in the first distance class.

\section{Detecting genetic bottlenecks}

To test our hypothesis about the reduction in the effective population size and consequent reduction in genetic diversity, we used the allele frequencies in the Bottleneck program, version 1.2 (Cornuet and Luikart, 1996), using the models infinite allele model of mutation (IAM) and stepwise mutation model (SMM). These two models were used to calculate the expected heterozygosity of the population at mutation-drift equilibrium, which were then compared to the level of heterozygosity found in the studied population. The mutation model for the ISSR loci is intermediate between the IAM and SMM; therefore, both of these were used (Luikart et al., 1998). The sign test $(\alpha=0.05)$ was used to identify significant recent genetic bottleneck based on the allele frequency (Cornuet and Luikart, 1996).

Genetics and Molecular Research 15 (4): gmr15049100 


\section{RESULTS}

\section{Genetic diversity and structure}

Of the 17 tested primers, 12 amplified the DNA of C. prunifera. Seven of these were selected (Table 1), which detected 93 loci with $100 \%$ polymorphism. The values of the observed alleles (2.00), polymorphic loci (93), and polymorphic loci percentage $(100 \%)$ were equal for the total population and for the three cohorts. The seedlings showed the greatest levels of genetic diversity $\left(H_{\mathrm{E}}=0.411\right.$ and $\left.H_{\mathrm{O}}=0.599\right)$, followed by juveniles and adults (Table 2).

AMOVA showed that there was more genetic variation within cohorts $(93.42 \%)$ than between cohorts $(6.58 \%)$ (Table 3$)$.

Table 1. Nucleotide sequence of ISSR primers, number of loci detected by it, and the PIC value of each primer.

\begin{tabular}{l|l|c|c}
\hline ISSR primer & Sequence (5'-3') & Loci & PIC \\
\hline UBC 813 (CT)8-T & CTCTCTCTCTCTCTCTT & 11 & 0.280 \\
\hline UBC 827 (AC)8G & ACACACACACACACACG & 9 & 0.264 \\
\hline UBC 840 (GA)8-YT & GAGAGAGAGAGAGAGAYT & 12 & 0.393 \\
\hline UBC 841 (GA)8-YC & GAGAGAGAGAGAGAGAYC & 18 & 0.444 \\
\hline UBC 842 (GA)8-YG & GAGAGAGAGAGAGAGAYG & 17 & 0.419 \\
\hline UBC 857 (AC)8-YG & ACACACACACACACACYG & 14 & 0.079 \\
\hline UBC 859 (TG)8-RC & TGTGTGTGTGTGTGTGRC & 12 & 0.057 \\
\hline Mean & & 13.28 & 0.277 \\
\hline
\end{tabular}

$\mathrm{R}=$ purine $(\mathrm{A}$ or $\mathrm{G}) ; \mathrm{Y}=$ pyrimidine $(\mathrm{C}$ or $\mathrm{T})$.

Table 2. Genetic diversity and spatial genetic structure for the life stages of Copernicia prunifera.

\begin{tabular}{l|c|c|c|c|c|c|c}
\hline & $\mathrm{N}$ & $N_{\mathrm{E}}$ & $H_{\mathrm{E}}$ & $H_{\mathrm{O}}$ & $F_{\mathrm{IJ}}$ & $b_{\log }$ & $S p$ \\
\hline Seedlings & 62 & $1.728 \pm 0.219$ & $0.411 \pm 0.079$ & $0.599 \pm 0.086$ & 0.069 & $-0.036^{*}$ & 0.040 \\
\hline Juveniles & 20 & $1.689 \pm 0.242$ & $0.394 \pm 0.095$ & $0.579 \pm 0.108$ & 0.172 & $-0.077^{*}$ & 0.093 \\
\hline Adults & 19 & $1.397 \pm 0.215$ & $0.267 \pm 0.114$ & $0.427 \pm 0.146$ & 0.211 & $-0.123^{*}$ & 0.156 \\
\hline Total & 101 & $1.667 \pm 0.209$ & $0.390 \pm 0.079$ & $0.576 \pm 0.088$ & 0.083 & $-0.048^{*}$ & 0.053 \\
\hline
\end{tabular}

\section{Bottleneck}

Using IAM, it was expected that the number of loci with heterozygosity excess was 37.09, whereas, the results showed 92 loci with heterozygosity excess. Therefore, the observed value of loci was more than twice of the expected value and was significant according to the sign test $(\mathrm{P}<0.0001)$. For SMM, the expected value of loci with heterozygosity excess was 42.59; however, the observed value was much higher (91 loci) and was also statistically significant $(\mathrm{P}<0.0001)$.

\section{Spatial genetic structure}

The developmental stages (seedlings and juveniles) of the population showed positive relatedness within the first distance class, from 0 to $4 \mathrm{~m}$ (Figures $2 \mathrm{~A}$ and $\mathrm{B}$, respectively), whereas the adults (Figure 2C) and total population (Figure 2D) showed significant relatedness up to the second distance class, i.e., from 0 to 8 and 0 to $9 \mathrm{~m}$, respectively. The seedlings showed negative relatedness in the fourth distance class (about 13 meters). In the subsequent

Genetics and Molecular Research 15 (4): gmr15049100 
distance classes, the distribution was random. The genetic divergence between the juveniles, adults, and all the individuals was significant in the third distance class, whereas the juveniles showed dissimilarity at 17 and $33 \mathrm{~m}$.
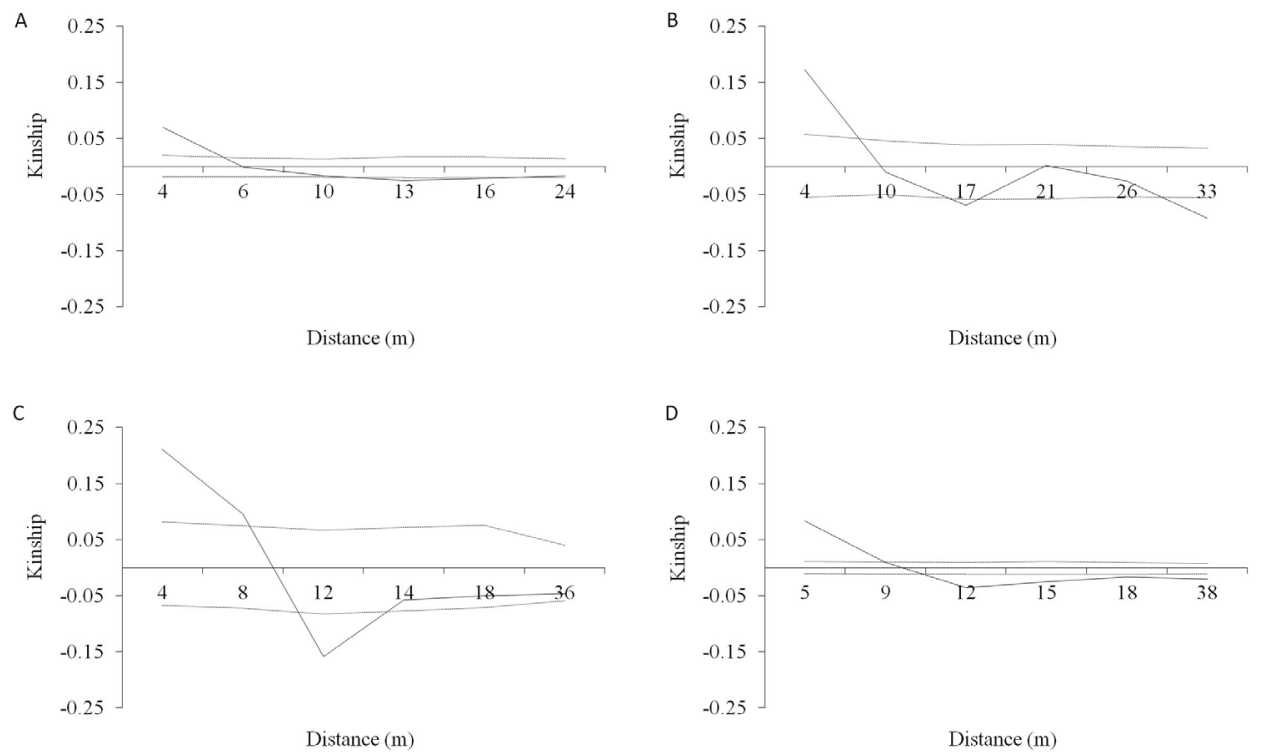

Figure 2. Correlogram of kinship coefficients of seedlings (A), juveniles (B), adults (C) and for all the Copernicia prunifera individuals (D). Dotted line indicates confidence interval.

The results of $S p$ statistics showed the same genetic structure in the total population as well as in the developmental stages $(\mathrm{P}<0.05)$ (Table 2). In the first distance class, the $S p$ value was highest for adults (0.156), followed by juveniles (0.093), and seedlings (0.040).

\section{DISCUSSION}

Our study showed 100\% polymorphism (93 loci), using seven selected ISSR primers. Srivashtav et al. (2013) used two ISSR primers to assess the genetic diversity of the species Phoenix dactylifera L. (Arecaceae) from a region in India. Total thirteen loci were found, among which 10 were polymorphic and three were monomorphic. Roncal et al. (2007) assessed the taxonomic distinction of two varieties of Geonoma macrostachys Mart. (Arecaeae) in the Amazon region using ISSR markers and observed 99 loci, among which $51.52 \%$ were polymorphic.

We found the lowest levels of diversity among the $C$. prunifera adults $\left(H_{\mathrm{E}}=0.267\right.$ and $H_{\mathrm{O}}=0.427$ ), possibly because they are remnants of a population that has suffered a genetic bottleneck. This conclusion is supported by the test for genetic bottleneck, discussed below. The significant differences between the levels of genetic diversity across generations within the population might be the result of natural selection or influx of genotypes from other populations (Epperson and Alvarez-Buylla, 1997; Vieira et al., 2010). Vieira et al. (2012) noted that environmental disturbances, limited seed dispersal near the mother plant, and low density of reproductive adults can determine the varying levels of relatedness between individuals and between life stages, as well as the degree of genetic diversity of the population.

Genetics and Molecular Research 15 (4): gmr15049100 
Using allozyme markers, Conte et al. (2003) observed no significant differences in the genetic diversity (Nei index) between the seedlings, juveniles, and adults of Euterpe edulis Mart. They attributed the similarity in genetic diversity to the large number of adult individuals in the population, which might compensate for the variability that is naturally lost through genetic drift. In our study, the significant differences observed in the levels of genetic diversity between the life stages and the greater molecular variation within the life stages can be associated with an influx of genotypes from other populations or random crossing among adult individuals in the studied population. Thus, further studies are necessary to evaluate the outcrossing rate of $C$. prunifera and its association with genetic structure.

The genetic bottleneck analysis showed that the population suffered a strong reduction in the effective size, possibly as a consequence of human activities in the region. We observed the evidence of cutting-down of C. prunifera and other species in the study area. On the other hand, according to Deshpande et al. (2001), the large number of loci with heterozygosity excess might be related to the fact that ISSR markers tend to generate more polymorphism than other markers, such as AFLP and RAPD. In this case, the simultaneous use of different molecular markers might shed light on this hypothesis.

Using microsatellite markers, Seoane et al. (2005) assessed the reproductive system of two E. edulis populations, one fragmented and the other continuous, and found a greater kinship value among the progeny of the continuous population $\left(F_{\mathrm{IJ}}=0.222\right)$ than that in the progeny of the fragmented population $\left(F_{\mathrm{IJ}}=0.193\right)$. Furthermore, Brandão et al. (2011) used 10 ISSR primers to identify the genetic distribution of Myrcia splendens (SW.) DC in a fragment-corridor system in southeastern Brazil. They found positive kinship values in two vegetation corridors, at distances of 20 and $70 \mathrm{~m}$. Several authors have suggested that genetic structuring between the life stages might be common among the tropical tree species (Conte et al., 2003; Seoane et al., 2005; Vieira et al., 2012). A possible explanation for SGS being found in the first distance class for C. prunifera is its restricted seed dispersal, where large number of fruits fall near the mother plant.

In this study, we observed that the SGS increases from seedling to the adult life stages, suggesting that the adult plants are from related parents. Similar results were found by Latouche-Hallé et al. (2003), whereas Kalisz et al. (2001) found a lower genetic diversity index for adults, supporting the hypothesis that more significant SGS is inversely related to the genetic diversity. In fact, the initial life stages of $C$. prunifera had greater $H_{\mathrm{E}}$ and less SGS, whereas the final life stage (adults) have lower $H_{\mathrm{E}}$ and higher SGS (Tables 1 and 3).

\section{Implications for conservation}

Our results show that $C$. prunifera plants have spatial structure up to a distance of 5 to $6 \mathrm{~m}$ in all the life stages, with spatial correlation between seedlings and adults, which indicates restricted dispersion around the parental plants. Among the developmental stages of C. prunifera, the regeneration stage (seedlings) was most genetically diverse and the majority of genotypic variations were found within the life stages. The life stages with the greatest genetic similarity were the juveniles and seedlings. In addition, the genetic bottleneck analysis suggests that the population was greatly reduced and consequently suffered a reduction in genotypes. Finally, SGS was found up to the second distance class for all the life stages, indicating that the individuals located in close proximity to one another are closely related.

To date, few studies have been conducted to analyze the genetic diversity of Copernicia species using molecular markers (Vieira et al., 2015). Therefore, this study presents novel

Genetics and Molecular Research 15 (4): gmr15049100 
genetic information not only about the genus Copernicia, but also about C. prunifera, which is important for further understanding of the Arecaceae family. Although it is not present in the list of endangered species, $C$. prunifera is increasingly being threatened by agricultural practices in northeastern Brazil (Sousa et al., 2015). Therefore, the preservation of this palm is of fundamental importance because, besides the ecological relationships that the species has with the natural environment, it is a source of income for many rural families and is an important factor in economic and social development. The data obtained in this study might contribute to the development of strategies for conservation and proper management of $C$. prunifera. For example, using such information, it is possible to select progeny arrays to produce seedlings with high levels of genetic diversity (Lowe et al., 2005). Based on our results, we recommend that trees selected for seed collection should be located at least $12 \mathrm{~m}$ apart, thereby, greatly reducing the probability of progeny arrays being closely related and contribute to the molecular diversity of the population. In addition, conservation plans must ensure that the size and structure of the population (e.g., number of individuals of reproductive age) presents sufficient genetic diversity to enable the species to maintain itself for a long time within the environment in which it occurs (Harris and Johnson, 2004).

\section{Conflicts of interest}

The authors declare no conflict of interest.

\section{ACKNOWLEDGMENTS}

Research supported by Conselho Nacional de Desenvolvimento Científico e Tecnológico $(\mathrm{CNPq})$. R.F. Sousa received a MSc scholarship from Coordenação de Aperfeiçoamento de Pessoal de Nível Superior (CAPES). We thank T.G.F. Rocha and R.A.R. Silva for field assistance. We acknowledge Dr. W.F. Molina for providing laboratory facilities and we thank Dr. E.R. Nimmo for editing the English of the manuscript.

\section{REFERENCES}

Brandão MM, Vieira FA and Carvalho D (2011). Fine-scale genetic structure of Myrcia splendens (Myrtaceae). Rev. Arvore 35: 957-964.

Brandão MM, Vieira FA, Nazareno AG and Carvalho D (2015). Genetic diversity of neotropical tree Myrcia splendens (Myrtaceae) in a fragment-corridor system in the Atlantic rainforest. Flora 216: 35-41. http://dx.doi.org/10.1016/j. flora.2015.07.006

Cestaro LA and Soares JJ (2004). Variações florística e estrutural e relações fitogeográficas de um fragmento de floresta decídua no Rio Grande do Norte, Brasil. Acta Bot. Bras. 18: 203-218. http://dx.doi.org/10.1590/S0102$\underline{33062004000200001}$

Condit R, Ashton PS, Baker P, Bunyavejchewin S, et al. (2000). Spatial patterns in the distribution of tropical tree species. Science 288: 1414-1418. http://dx.doi.org/10.1126/science.288.5470.1414

Conte R, Nodari RO, Vencovsky R and dos Reis MS (2003). Genetic diversity and recruitment of the tropical palm, Euterpe edulis Mart., in a natural population from the Brazilian Atlantic Forest. Heredity (Edinb) 91: 401-406. http:// dx.doi.org/10.1038/sj.hdy.6800347

Cornuet JM and Luikart G (1996). Description and power analysis of two tests for detecting recent population bottlenecks from allele frequency data. Genetics 144: 2001-2014.

Cota LG, Vieira FA, Melo Júnior AF, Brandão MM, et al. (2011). Genetic diversity of Annona crassiflora (Annonaceae) in northern Minas Gerais State. Genet. Mol. Res. 10: 2172-2180. http://dx.doi.org/10.4238/vol10-3gmr1188

Genetics and Molecular Research 15 (4): gmr15049100 
Deshpande AU, Apte GS, Bahulikar RA, Lagu MD, et al. (2001). Genetic diversity across natural populations of three montane plant species from the Western Ghats, India revealed by intersimple sequence repeats. Mol. Ecol. 10: $2397-$ 2408. http://dx.doi.org/10.1046/j.0962-1083.2001.01379.x

Doyle JJ and Doyle JL (1990). Isolation of plant DNA from fresh tissue. Focus 12: 13-15.

Epperson BK and Alvarez-Buylla ER (1997). Limited seed dispersal and genetic structure in life stages of Cecropia obtusifolia. Evolution 51: 275-282. http://dx.doi.org/10.2307/2410981

Excoffier L, Laval G and Schneider S (2007). Arlequin (version 3.0): an integrated software package for population genetics data analysis. Evol. Bioinform. Online 1: 47-50.

Gonçalves AC, Reis CAF, Vieira FA and Carvalho D (2010). Spatial genetic structure in natural populations of Dimorphandra mollis (Fabaceae) in the north of Minas Gerais State, Brazil. Braz. J. Bot. 33: 325-332. http://dx.doi. org/10.1590/S0100-84042010000200013

Hardy OJ (2003). Estimation of pairwise relatedness between individuals and characterization of isolation-bydistance processes using dominant genetic markers. Mol. Ecol. 12: 1577-1588. http://dx.doi.org/10.1046/j.1365294X.2003.01835.x

Hardy OJ and Vekemans X (2002). SPAGeDi: a versatile computer program to analyse spatial genetic structure at the individual or population levels. Mol. Ecol. Resour. 2: 618-620. http://dx.doi.org/10.1046/j.1471-8286.2002.00305.x

Harris LF and Johnson SD (2004). The consequences of habitat fragmentation for plant-pollinator mutualisms. Int. J. Trop. Insect Sci. 24: 29-43.

Hoffmann AA and Willi Y (2008). Detecting genetic responses to environmental change. Nat. Rev. Genet. 9: 421-432. http://dx.doi.org/10.1038/nrg2339

Kalisz S, Nason JD, Hanzawa FM and Tonsor SJ (2001). Spatial population genetic structure in Trillium grandiflorum: the roles of dispersal, mating, history, and selection. Evolution 55: 1560-1568. http://dx.doi.org/10.1111/j.0014-3820.2001. $\underline{\text { tb00675.x }}$

Lacerda CMB and Kageyama PY (2003). Estrutura genética espacial de duas populações nativas de Myracrodruon urundeuva M. Alemão na região semi-árida, Brasil. Rev. Arvore 27: 145-150. http://dx.doi.org/10.1590/S0100$\underline{67622003000200004}$

Latouche-Hallé C, Ramboer A, Bandou E, Caron H, et al. (2003). Nuclear and chloroplast genetic structure indicate finescale spatial dynamics in a neotropical tree population. Heredity (Edinb) 91: 181-190. http://dx.doi.org/10.1038/ sj.hdy. 6800296

Lowe AJ, Boshier D, Ward M, Bacles CFE, et al. (2005). Genetic resource impacts of habitat loss and degradation; reconciling empirical evidence and predicted theory for neotropical trees. Heredity (Edinb) 95: 255-273. http:// dx.doi.org/10.1038/sj.hdy. 6800725

Luikart G, Allendorf FW, Cornuet JM and Sherwin WB (1998). Distortion of allele frequency distributions provides a test for recent population bottlenecks. J. Hered. 89: 238-247. http://dx.doi.org/10.1093/jhered/89.3.238

Môro J, Silva MAS and Geraldo JS (1999). Methodology for kariological study of Brazilian palms. ISHS Acta Horticulturae 486: 225-228. http://dx.doi.org/10.17660/ActaHortic.1999.486.33

$\mathrm{Ng}$ KKS, Lee SL and Koh CL (2004). Spatial structure and genetic diversity of two tropical tree species with contrasting breeding systems and different ploidy levels. Mol. Ecol. 13: 657-669. http://dx.doi.org/10.1046/j.1365294X.2004.02094.X

Reddy MP, Sarla N and Siddiq EA (2002). Inter simple sequence repeat (ISSR) polymorphism and its application in plant breeding. Euphytica 128: 9-17. http://dx.doi.org/10.1023/A:1020691618797

Rocha TGF, Silva RAR, Dantas EX and Vieira FA (2015). Fenologia da Copernicia prunifera (Arecaceae) em uma área de caatinga do Rio Grande do Norte. Cerne 21: 673-681. http://dx.doi.org/10.1590/01047760201521041758

Rodrigues LC, Silva AA, Silva RB, Oliveira AFM, et al. (2013). Conhecimento e uso da carnaúba e da algaroba em comunidades do sertão do Rio Grande do Norte, nordeste do Brasil. Rev. Arvore 37: 451-457. http://dx.doi. org $/ 10.1590 / \mathrm{S} 0100-67622013000300008$

Roncal J, Francisco-Ortega J and Lewis CE (2007). An evaluation of the taxonomic distinctness of two Geonomama crostachys (Arecaceae) varieties based on inter-simple sequence repeat (ISSR) variation. Bot. J. Linn. Soc. 153: 381392. http://dx.doi.org/10.1111/j.1095-8339.2007.00619.x

Rossato M, Barbieri RL, Schäfer A and Zacaria J (2007). Caracterização molecular de populações de palmeiras do gênero Butia do Rio Grande do Sul através de marcadores ISSR. Magistra 19: 311-318.

Seoane CES, Sebbenn AM and Kageyama PY (2005). Sistema de reprodução em duas populações naturais de Euterpe edulis M. sob diferentes condições de fragmentação florestal. Sci. Forum 69: 13-24.

Silva MS, Vieira FA and Carvalho D (2011). Diversity and genetic structure in natural populations of Geonoma schottiana Mart (Arecaceae): implications for conservation. Cerne 17: 195-201. http://dx.doi.org/10.1590/S0104$\underline{77602011000200006}$

Genetics and Molecular Research 15 (4): gmr15049100 
Sousa RF, Silva RAR, Rocha TGF, Santana JAS, et al. (2015). Etnoecologia e etnobotânica da palmeira carnaúba no semiárido brasileiro. Cerne 21: 587-594. http://dx.doi.org/10.1590/01047760201521041764

Souza HAVE and Lovato MB (2010). Genetic diversity and structure of the critically endangered tree Dimorphandra wilsonii and of the widespread in the Brazilian Cerrado Dimorphandra mollis: implications for conservation. Biochem. Syst. Ecol. 38: 49-56. http://dx.doi.org/10.1016/j.bse.2009.12.038

Srivashtav VS, Kapadia CV, Mahatma MK, Jha SK, et al. (2013). Genetic diversity analysis of date palm (Phoenix dactylifera L.) in the Kutch region of India using RAPD and ISSR markers. Emir. J. Food Agric 25: 907-915. http:// dx.doi.org/10.9755/ejfa.v25i11.14325

Van Treuren R, Bijlsma N, van Delden W and Ouborg J (1991). The significance of genetic erosion in the process of extinction. I. Genetic differentiation in Salvia pratensis and Scabiosa columbaria in relation to population size. Heredity 66: 181-189. http://dx.doi.org/10.1038/hdy.1991.23

Vekemans X and Hardy OJ (2004). New insights from fine-scale spatial genetic structure analyses in plant populations. Mol. Ecol. 13: 921-935. http://dx.doi.org/10.1046/j.1365-294X.2004.02076.x

Vieira FdeA, de Carvalho D, Higuchi P, Machado EL, et al. (2010). Spatial pattern and fine-scale genetic structure indicating recent colonization of the palm Euterpe edulis in a Brazilian Atlantic forest fragment. Biochem. Genet. 48: 96-103. http://dx.doi.org/10.1007/s10528-009-9298-3

Vieira FA, Fajardo CG, Souza AM, Reis CAF, et al. (2012). Fine-scale genetic dynamics of a dominant neotropical tree in the threatened Brazilian Atlantic Rainforest. Tree Genet. Genomes 8: 1191-1201. http://dx.doi.org/10.1007/s11295012-0506-7

Vieira FA, Sousa RF, Silva RAR, Fajardo CG, et al. (2015). Diversidade genética de Copernicia prunifera com o uso de marcadores moleculares ISSR. Agraria 10: 525-531. http://dx.doi.org/10.5039/agraria.v10i4a5040

White PS and Walker JL (1997). Approximating nature's variation: selecting and using reference information in restoration ecology. Restor. Ecol. 5: 338-349. http://dx.doi.org/10.1046/j.1526-100X.1997.00547.x

Yeh FC, Yang RC, Boyle TBJ, Ye ZH, et al. (1997). Pop-gene, theuser-friendly shareware for population genetic analysis molecular biology and biotechnology center. Molecular Biology and Biotechnology Center, University of Alberta, Ed-monton, Alberta, Canada.

Zietkiewicz E, Rafalski A and Labuda D (1994). Genome fingerprinting by simple sequence repeat (SSR)-anchored polymerase chain reaction amplification. Genomics 20: 176-183. http://dx.doi.org/10.1006/geno.1994.1151

Genetics and Molecular Research 15 (4): gmr15049100 